Article

\title{
Ethanolic Extract of Moringa oleifera Leaves Influences NF- $\kappa$ B Signaling Pathway to Restore Kidney Tissue from Cobalt-Mediated Oxidative Injury and Inflammation in Rats
}

\author{
Mohamed M. Abdel-Daim ${ }^{1,2}{ }^{(}$, Samah R. Khalil ${ }^{3, *}$, Ashraf Awad ${ }^{4}$, Ehsan H. Abu Zeid ${ }^{3}{ }^{(0)}$, \\ Reda Abd El-Aziz ${ }^{5}$ and Hamed A. El-Serehy ${ }^{1}$ \\ 1 Department of Zoology, College of Science, King Saud University, P.O. Box 2455, Riyadh 11451, Saudi Arabia; \\ abdeldaim.m@vet.suez.edu.eg (M.M.A.-D.); helserehy@ksu.edu.sa (H.A.E.-S.) \\ 2 Pharmacology Department, Faculty of Veterinary Medicine, Suez Canal University, Ismailia 41522, Egypt \\ 3 Forensic Medicine and Toxicology Department, Faculty of Veterinary Medicine, Zagazig University, \\ Zagazig 44511, Egypt; ehelsharkawy@zu.edu.eg \\ 4 Animal wealth Development Department, Faculty of Veterinary Medicine, Zagazig University, \\ Zagazig 44511, Egypt; afsawad@zu.edu.eg \\ 5 Physiology Department, Faculty of Veterinary Medicine, Zagazig University, Zagazig 44511, Egypt; \\ mmreda@zu.edu.eg \\ * Correspondence: resamah@zu.edu.eg; Tel.: +201-033-966-915
}

Received: 15 March 2020; Accepted: 7 April 2020; Published: 9 April 2020

\begin{abstract}
This study aimed to describe the protective efficacy of Moringa oleifera ethanolic extract (MOEE) against the impact of cobalt chloride $\left(\mathrm{CoCl}_{2}\right)$ exposure on the rat's kidney. Fifty male rats were assigned to five equal groups: a control group, a MOEE-administered group ( $400 \mathrm{mg} / \mathrm{kg}$ body weight (bw), daily via gastric tube), a $\mathrm{CoCl}_{2}$-intoxicated group $(300 \mathrm{mg} / \mathrm{L}$, daily in drinking water), a protective group, and a therapeutic co-administered group that received MOEE prior to or following and concurrently with $\mathrm{CoCl}_{2}$, respectively. The antioxidant status indices (superoxide dismutase (SOD), catalase (CAT), and reduced glutathione (GSH)), oxidative stress markers (hydrogen peroxide $\left(\mathrm{H}_{2} \mathrm{O}_{2}\right)$, 8-hydroxy-2-deoxyguanosine (8-OHdG), and malondialdehyde (MDA)), and inflammatory response markers (nitric oxide (NO), tumor necrosis factor (TNF- $\alpha$ ), myeloperoxidase (MPO), and C-reactive protein (CRP)) were evaluated. The expression profiles of pro-inflammatory cytokines (nuclear factor-kappa B (NF-kB) and interleukin-6 (IL-6)) were also measured by real-time quantitative polymerase chain reaction (qRT-PCR). The results showed that $\mathrm{CoCl}_{2}$ exposure was associated with significant elevations of oxidative stress and inflammatory indices with reductions in the endogenous tissue antioxidants' concentrations. Moreover, $\mathrm{CoCl}_{2}$ enhanced the activity of the NF- $\mathrm{kB}$ inflammatory-signaling pathway that plays a role in the associated inflammation of the kidney. MOEE ameliorated $\mathrm{CoCl}_{2}$-induced renal oxidative damage and inflammatory injury with the suppression of the mRNA expression pattern of pro-inflammatory cytokine-encoding genes. MOEE is more effective when it is administered with $\mathrm{CoCl}_{2}$ exposure as a prophylactic regimen. In conclusion, MOEE administration exhibited protective effects in counteracting $\mathrm{CoCl}_{2}$-induced renal injury in rats.
\end{abstract}

Keywords: Moringa oleifera; cobalt; NF- $\mathrm{kB}$; myeloperoxidase; C-reactive protein; TNF- $\alpha$; IL-6; 8-hydroxy-2-deoxyguanosine

\section{Introduction}

Cobalt $\left(\mathrm{Co}^{2+}\right)$ is a trace element that is involved in the normal physiological functions of the nervous system and bone marrow erythropoiesis. Therefore, $\mathrm{Co}^{2+}$ nutritional deficiency may 
manifest as pernicious anemia, growth retardation, digestive disturbances, and myelination defects [1]. Yet, excessive exposure of humans and animals to high concentrations of $\mathrm{Co}^{2+}$ can occur through the inhalation of contaminated air and dietary routes as consumption of contaminated food, water, and cobalt-containing supplements. Numerous cases of $\mathrm{Co}^{2+}$ toxicity have been reported following occupational exposure and the use of industrial products as electrochemical products, rechargeable batteries, ceramics, cemented tungsten-cobalt, paints, and varnishes [2]. Over-the-counter supplements and illegal doping of athletes and racehorses with cobalt-containing products are potential sources of excessive exposure [3]. Further, cobalt has been used in various metal dental alloys, such as porcelain-fused-to-metal crowns, bridges, and dental implants [4]. The release of particulate wear debris from $\mathrm{Co}^{2+}$ alloys into the blood and various tissues, including the liver and kidneys, results in local cell toxicity and tissue infiltration with macrophages, which lead to bone and soft tissue injuries, as well as sensory and motor impairments [5]. Pan et al. found that cobalt-chrome alloys cause transient trace metal accumulation and apoptotic changes in the kidney and liver tissues that can be diminished or even terminated by the removal of the alloys from Syrian hamsters [6]. The International Agency for Research on Cancer (IARC) has listed cobalt compounds as possibly carcinogenic agents to humans (Group 2B) [7]. Thus, studies on the potential adverse effects and the related health risks of cobalt in biological systems and the environment are pertinent. A recent extensive review by Leyssens et al. [8] covered the historical and contemporary cobalt sources in different exposure settings and the related intake routes, kinetics, underlying toxicity mechanisms, and a critical evaluation of the known systemic human health effects, providing a comprehensive quantitative exposure and risk assessment. The systemic health effects are likely to occur at blood Co concentrations higher than $300 \mu \mathrm{g} / \mathrm{L}$ [8]. Mostly, cobalt toxicity investigations have been mainly performed for its genotoxicity [9], tissue hypoxia [10,11], and cytotoxicity [12].

Nutraceuticals have been extensively studied in recent years with the goal of finding safe therapeutics of natural origin instead of relying only on pharmaceuticals. Nutraceuticals are constituted of phytocomplexes if they are derived from a plant origin, and a blend of the secondary metabolites if they are derived from an animal origin [13]. Within nutraceuticals of vegetal origin, more than 8000 phenolic constituents were characterized, representing one of the most widely distributed class of plant secondary metabolites. The main concern regarding polyphenols is related to their high potential application for food preservation and for therapeutic beneficial use [14]. Besides, the use of natural antioxidant products from plant sources has shown promising evidence in ameliorating the toxicity of diverse xenobiotics in in vivo models [15-19].

Moringa oleifera (MO) Lam. is grown in many countries of the tropics and sub-tropics. Almost every part of the MO tree is useful as food supplements, traditional medicine, and for industrial purposes. The wide use of MO is due to its highly desirable nutritional content, including vitamins, amino acids, minerals, and fatty acids, besides various types of antioxidants including flavonoids, ascorbic acid, glucsinolates, carotenoids, and phenolics. The leaves of MO are high in nutritional constituents because of the relatively low moisture content compared with most vegetables [20]. A wide degree of safety of different $\mathrm{MO}$ extracts was reported, such as for example the median lethal dose $\left(\mathrm{LD}_{50}\right)$ of alcoholic extract of MO leaves up to $5 \mathrm{gm} / \mathrm{kg}$ body weight (bw) [21]. in vivo human and animals as well as in vitro studies proved that various extracts of MO leaves possess different therapeutic effects, such as anti-inflammatory, hypolipidemic, antioxidant, anti-diabetic, and chemoprotective (hepatic, cardiac, renal, and nervous) activities [11,22-25].

Oxidative stress has an important role in the development and progression of the inflammatory response to various pollutant exposure; therefore, the reciprocal relationship between oxidative injury and inflammatory processes was considered [26]. Oxidants potentiate all phases of the inflammatory process, including the production of pro-inflammatory cytokines, activation of the signaling pathways, and the adaptive cellular response [27]. The present investigation was planned to assess the role of the ethanolic extract of Moringa oleifera leaves (MOEE) in protecting the kidney tissue against $\mathrm{CoCl}_{2}$ toxicity in rats. Moreover, we assessed the changes in the expression of genes that act as convenient 
molecular endpoints for the inflammatory response, where the generation of reactive oxygen species (ROS) is closely linked to inflammation-triggered pathways.

\section{Material and Methods}

\subsection{Ethical Statement}

The authors declared that all procedures in the present study were conducted in strict compliance with the ethical standards of the National Institutes of Health (NIH) guidelines on the care and use of laboratory animals. Prior approval was provided from the Institutional Animal Care and Use Committee of Zagazig University (ZU-IACUC/2/F/80/2018). All efforts were considered to reduce the suffering of animals prior to and throughout the experiment and sampling.

\subsection{Tested Chemicals and Plant Extract}

Cobalt dichloride $\left(\mathrm{CoCl}_{2} \times 6 \mathrm{H}_{2} \mathrm{O}\right)(\mathrm{CAS}$ No. $7791-13-1)$ with $97 \%$ purity was obtained from Sigma-Aldrich Co. (St. Louis, MO, USA). Moringa oleifera (MO) plant was kindly provided from the Egyptian Scientific Society of Moringa. The botanical identification of the MO plant leaves was performed by Prof. Abou El Fetooh Abd-Allah, Chairman of the Egyptian Scientific Association for Moringa, National Research Center, Cairo, Egypt.

\subsection{Preparation of the Ethanolic Extract of the Leaves of Moringa oleifera}

The MOEE was prepared as follows: The plant leaves were cleaned by washing with distilled water and dried at room temperature for 21 days. The dried MO leaves were crushed into fine powder by a high-speed milling machine. Then, $1000 \mathrm{mg}$ from the obtained powder was extracted in $1000 \mathrm{~mL}$ of ethanol (absolute) for $48 \mathrm{~h}$ and filtered through filter paper ( $2 \mu \mathrm{m}$-sized pores) for two times. The resultant ethanolic extract was evaporated using a rotary evaporator at $50^{\circ} \mathrm{C}$. The residual yield of the obtained MOEE extract was $78.3 \mathrm{gm}$ per $1000 \mathrm{~g}$ of dried powder. The obtained extract was reconstituted in a brown bottle ( $1 \mathrm{gm}$ of extract: $10 \mathrm{~mL}$ distilled water) and was stored at $4{ }^{\circ} \mathrm{C}$ until use (Figure 1).

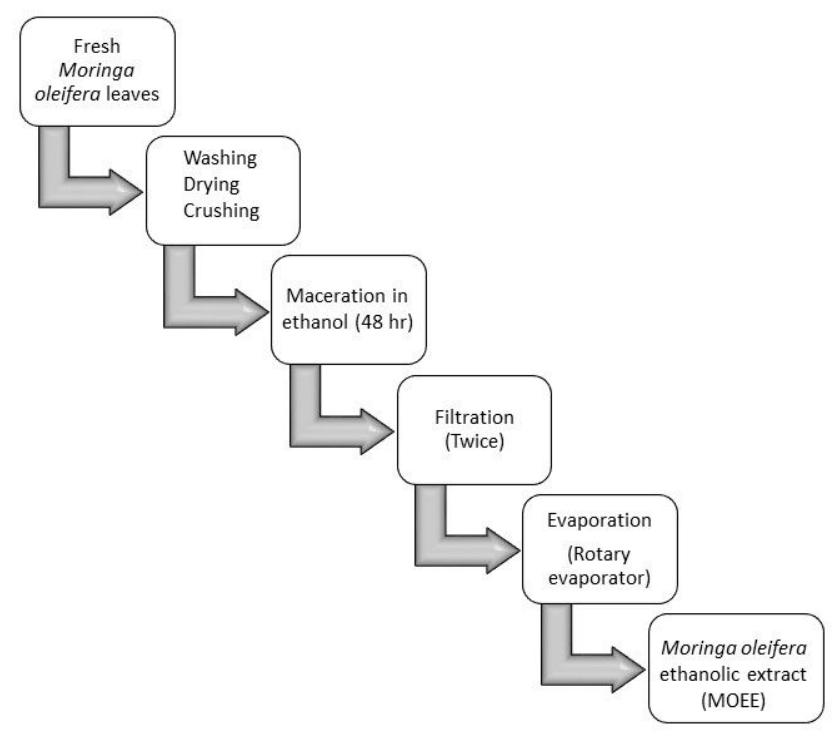

Figure 1. Scheme of procedure for preparation of Moringa oleifera ethanolic extract (MOEE).

\subsection{Gas Chromatography/Mass Spectrometry Analysis (GC-MS) of MOEE Bioactive Chemical Constituents}

MOEE was subjected to GC-MS analysis using the model instrument, Trace GC 1310-TSQ mass spectrometer (Thermo Scientific, Austin, TX, USA) with a direct capillary column TG-5MS 
(30 $\mathrm{m} \times 0.25 \mathrm{~mm} \times 0.25 \mu \mathrm{m}$ film thickness). The column oven temperature was initially held at $55^{\circ} \mathrm{C}$ and then increased by $5{ }^{\circ} \mathrm{C} / \mathrm{min}$ to $200{ }^{\circ} \mathrm{C}$ with a two-min hold; then, it was increased to 300 with $20 \mathrm{C} / \mathrm{min}$ and held for $3 \mathrm{~min}$. The injector temperature was kept at $270{ }^{\circ} \mathrm{C}$. Helium (99.9\%) was used as a carrier gas at a constant flow rate of $1 \mathrm{~mL} / \mathrm{min}$. The solvent delay was $2 \mathrm{~min}$, and $1 \mu \mathrm{L}$ of sample was injected automatically using an Autosampler AS3000 coupled with GC in the split mode. Electron ionization (EI) mass spectra were collected at $70 \mathrm{eV}$ ionization voltages over the range of m/z 50-600 in full scan mode. The ion source and transfer line temperatures were set at $200{ }^{\circ} \mathrm{C}$ and $270{ }^{\circ} \mathrm{C}$ respectively. The elution time allowed for identifying compounds is $40 \mathrm{~min}$. The components were identified by comparison of their retention times and mass spectra with those of the two important commercial libraries, the National Institute of Standards and Technology (NIST) mass spectral library (version 11) contains the EI spectra of more than 200,000 compounds (213,000 spectra), and the Wiley Registry (9th edition) contains the EI spectra of almost 600,000 unique compounds $(662,780)$ [28].

\subsection{Experimental Animals and Procedures}

The experiment was performed in 50 Sprague-Dawley male rats weighing 145-160 gm. Animals were caged under constant conditions for 10 days $\left(21-24{ }^{\circ} \mathrm{C}, 50-60 \%\right.$ relative humidity), where they had access to food and water ad libitum. Experimental animals were classified into five groups, where the number of animals used per each treatment was kept to a minimum of 10. The 1st group (Control) received only distilled water via oral administration. The 2nd group (MOEE) orally received $400 \mathrm{mg}$ $\mathrm{MOEE} / \mathrm{kg}$ bw/day for six weeks [11]. The 3rd group $\left(\mathrm{CoCl}_{2}\right)$ received $300 \mathrm{mg} / \mathrm{L}$ freshly prepared $\mathrm{CoCl}_{2}$ solution in drinking water for four weeks [29]. Rats in the 4 th group (prophylactic; $\mathrm{MOEE} / \mathrm{CoCl} \mathrm{C}_{2}+$ MOEE) received MOEE for two weeks prior to and four weeks concurrently with $\mathrm{CoCl}_{2}$ exposure. Rats in the 5th group (therapeutic; $\mathrm{CoCl}_{2}+\mathrm{MOEE} / \mathrm{MOEE}$ ) co-received both MOEE for four weeks concurrently with and two weeks following $\mathrm{CoCl}_{2}$ exposure at the previously described doses and regimens (Figure 2). The selected dose of $\mathrm{CoCl}_{2}$ in this study was carried out based on the results of previous work of Awoyemi et al. [29], where it induced tissue damage via oxidative stress, inflammation, and apoptosis in a dose-dependent manner. The ethanolic extract of MO leaves was found to increase the protective activity of the antioxidant system and slow the pathological development of tissue alterations, which was induced by xenobiotic exposure when administrated at the level of $400 \mathrm{mg} / \mathrm{kg}$ bw $[11,25]$.

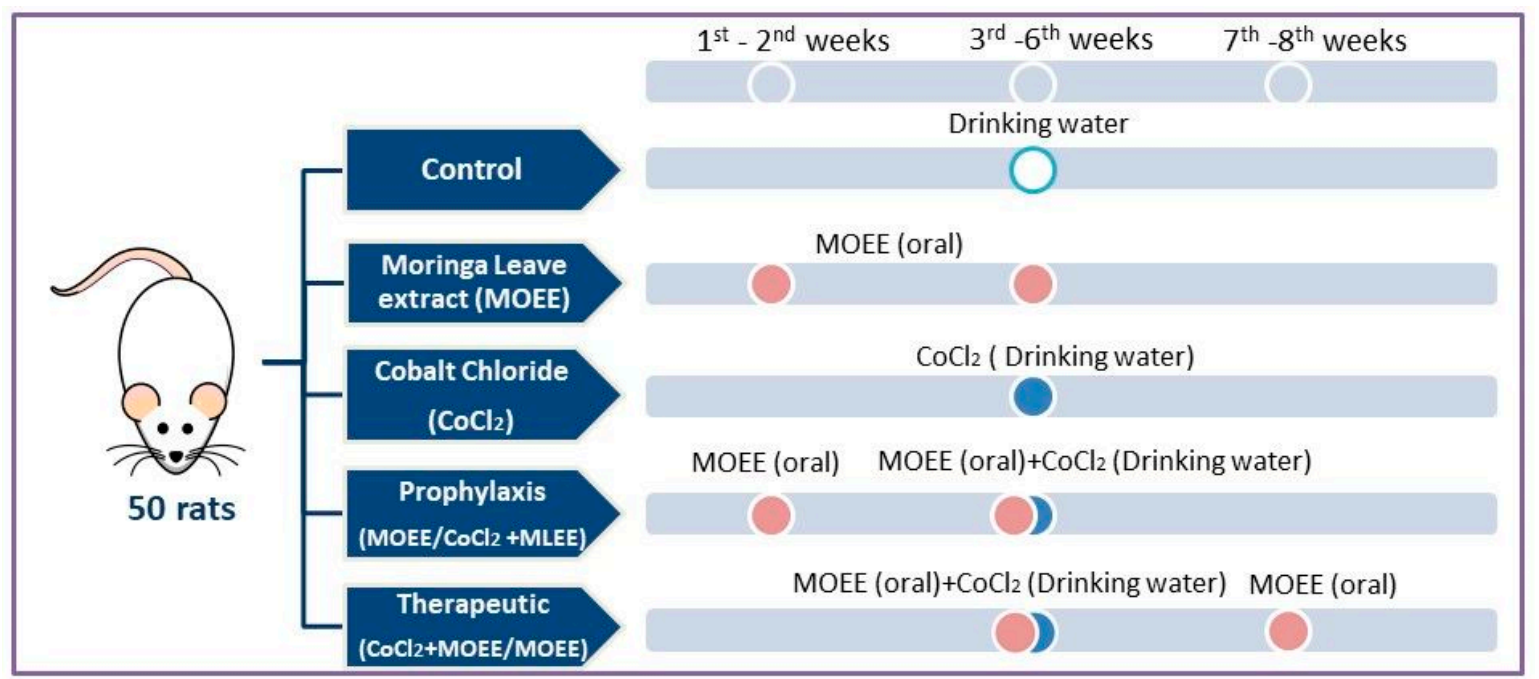

Figure 2. Experimental groups and treatments: MOEE: Moringa oleifera leave ethanolic extract (400 mg/kg body weight (bw), orally) and $\mathrm{CoCl}_{2}$ : cobalt chloride (300 mg/L in drinking water).

At the end of the experimental period, the final body weight of rats in all groups was measured to estimate the changes in body weight. In addition, whole blood samples were withdrawn from 
the orbital plexus into collection tubes by puncturing the plexus by a capillary tube. The obtained blood was subjected to centrifugation at $3000 \mathrm{rpm}$ for $15 \mathrm{~min}$ for serum separation; serum was aspirated and kept at $-20^{\circ} \mathrm{C}$ for biochemical assessment of renal tissue injury markers, protein profile, and 8-hydroxy-2-deoxyguanosine (8-OhdG). Animals of all the experimental groups were euthanized by cervical dislocation, and the renal tissue samples were dissected and weighed for calculation of relative weight. The dissected specimens were assigned into two sets; one set was used for homogenate preparation where the tissue was homogenized in phosphate buffer saline (1XPBS) (100 mg tissue/mL PBS), then centrifuged for 5 minutes $\left(5000 \times \mathrm{g} \mathrm{rpm}\right.$ at $\left.4{ }^{\circ} \mathrm{C}\right)$, and the supernatants were collected to measure tissue concentrations of the inflammatory, oxidative, and antioxidant markers. As well, the second set was immersed in liquid nitrogen and preserved at $-80^{\circ} \mathrm{C}$ until RNA extraction for gene expression analysis.

\subsection{Biochemical Estimation}

\subsubsection{Renal Injury Markers and Protein Profile}

The renal injury markers (Creatinine, and urea) and protein profile (Total protein and albumin) were quantitatively estimated in the serum samples by colorimetric BIOMED Diagnostic Egy Chem kits (Badr city, Egypt), following the manufacturer's instructions. The globulin level and albumin/globulin ratio were calculated.

\subsubsection{Oxidative Stress/Antioxidant Status Markers}

A hydrogen peroxide $\left(\mathrm{H}_{2} \mathrm{O}_{2}\right)$ colorimetric assay kit was used to estimate the level of $\mathrm{H}_{2} \mathrm{O}_{2}$ in the serum (Catalog No. MBS841818; MyBioSource, San Diego, United States). A quantitative determination of serum 8-hydroxy-2-deoxyguanosine (8-OHdG) was done by rat enzyme-linked immunosorbent assay (ELISA) (Catalog. No. KA0444; Abnova Co., Taiwan), following the producer's guidelines. The lipid peroxidation product (Malondialdehyde; MDA) in renal tissue were estimated calorimetrically assayed as reported by Ohkawa et al. [30]. The determination of antioxidants status including catalase (CAT), superoxide dismutase (SOD) activity, and reduced glutathione (GSH) level was carried out following the previous described methods [31-33].

\subsubsection{Inflammatory Response Markers}

Rat myeloperoxidase (MPO), tumor necrosis factor- $\alpha$ (TNF- $\alpha$ ), and C-reactive protein (CRP) ELISA kits and nitric oxide (NO) colorimetric kits were used and supplied from MyBioSource, San Diego, USA. (Catalog No. MBS704859, MBS267737, MBS2508830, and MBS243214, respectively). The quantitative estimation of these biomarkers was done following the manufacturer's recommended procedures.

\subsection{Real-Time Quantitative PCR (RT-qPCR) Analysis of Genes Encoding Inflammation (Pro-Inflammatory Cytokines)}

Total RNA was extracted from the frozen kidney specimens using the RNeasy Mini Kit (Qiagen, Germany) followed by the creation of the first-strand cDNA, which was reverse-transcribed from the extracted total RNA using a QuantiTect Reverse Transcription kit (Qiagen, Heidelberg, Germany). The primer sequences needed for the RT-PCR analysis are nuclear factor-kappa B (NF-kB) primers, 5-GCTTTGCAAACCTGG GAATA-3 and R: 5-CAAGGTCAGAAT GCACCAGA-3 [34]; interleukin (IL-6) primers, F: 5' - AAAGCCAGAGTC ATTCAGAGC-3', R: 5' - GAGCATTGGAAGTTGGGGTA-3' (NM_012589.2); and glyceraldehyde-3-phosphate dehydrogenase (GAPDH) primers, F: 5' -TGACGT GGACATCCGCAAAG-3', R: 5'-CTGGAAGGTGGACAGCGGAGG-3' [35].

A Rotor-Gene Q cycler (Qiagen, Germany) was used to perform the RT-qPCR analysis using QuantiTect SYBR Green PCR kits (Qiagen, Germany) and both primers of each gene. The PCR mixture components were $12.5 \mu \mathrm{L} 2 \times$ SYBR Green PCR Master Mix, $1 \mu \mathrm{L}$ of each primer $(10 \mathrm{pmol} / \mathrm{mL}), 2 \mu \mathrm{L}$ cDNA, and $8.5 \mu \mathrm{L}$ RNase-free water in a total volume of $25 \mu \mathrm{L}$. The thermal cycling operations were 
adjusted as follows: NF-kB, GAPDH (40 cycles of $95^{\circ} \mathrm{C}$ for $10 \mathrm{~s}$, (GAPDH: $\left.54{ }^{\circ} \mathrm{C}, \mathrm{NF}-\mathrm{kB}: 60^{\circ} \mathrm{C}\right)$ for $10 \mathrm{~s}$ and at $72{ }^{\circ} \mathrm{C}$ for $15 \mathrm{~s}$. IL-6 (40 cycles at $95{ }^{\circ} \mathrm{C}$ for $20 \mathrm{~s}$, at $60{ }^{\circ} \mathrm{C}$ for $15 \mathrm{~s}$, and at $72{ }^{\circ} \mathrm{C}$ for $\left.15 \mathrm{~s}\right)$. The relative fold change in the expression of target genes were estimated by the comparative $2^{-\Delta \Delta C t}$ method (Ct: cycle threshold) [36] with the GAPDH gene as an internal control to normalize the target gene expression level.

\subsection{Data Analysis}

The data were tested for normality using the Shapiro-Wilk W test and homogeneity of variances. One-way ANOVA test was conducted to test the statistical differences between treatment groups, using the SPSS 16.0 computer program (IBM Inc, Armonk, NY). The Tukey's multiple comparisons post-hoc test was done later to compare the mean values among these groups. Cases of significance were assumed on a $p$-value of less than 0.05 .

\section{Results}

\subsection{GC-MS Profiling of the MOEE}

The various bioactive compounds of the extract were characterized and identified by GC-MS analysis. According to GC-MS results, MOEE consists of 27 chemical components with different retention times, belonging to different chemical classes. The most identified components included eugenol (39.38\%), $\alpha$-bisabolol (15\%), bisabolol oxide B (6.19\%), thymol (4.74\%), and menthol (3.41\%). The other components included d-carvone (1.36\%), malonic acid (1.28\%), neophytadiene (1.23\%), and cinnamaldehyde (1.04\%) (Figure 3, Table 1).



Figure 3. GC-MS based chemical profiling of MOEE. 
Table 1. Bioactive chemical constituents assigned in MOEE by GC-MS analysis.

\begin{tabular}{|c|c|c|c|c|c|}
\hline Bioactive Chemical Constituents & Chemical Formula & Mass Weight (MW) & Matching Factor (MF) & Retention Time (RT) (min) & Area $\%$ \\
\hline Eugenol: 4-allyl-2-methoxyphenol & $\mathrm{C}_{10} \mathrm{H}_{12} \mathrm{O}_{2}$ & 164 & 951 & 15.82 & 39.38 \\
\hline$\alpha$-Bisabolol & $\mathrm{C}_{15} \mathrm{H}_{26} \mathrm{O}$ & 222 & 877 & 25.09 & 15.00 \\
\hline 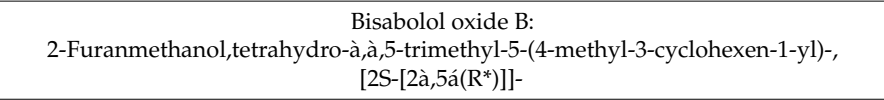 & $\mathrm{C}_{15} \mathrm{H}_{26} \mathrm{O}_{2}$ & 238 & 927 & 23.08 & 6.19 \\
\hline E-dipropylene glycol & $\mathrm{C}_{6} \mathrm{H}_{14} \mathrm{O}_{3}$ & 134 & 943 & 7.53 & 4.84 \\
\hline Thymol: 2-isopropyl-5-methylphenol & $\mathrm{C}_{10} \mathrm{H}_{14} \mathrm{O}$ & 150 & 918 & 14.15 & 4.74 \\
\hline $\begin{array}{c}\text { Menthol: 1'-(butyn-3-one-1-yl)-, (1S,2S,5R)- } \\
\text { 4-(1-Hydroxy-2-isopropyl-5-methylcyclohexyl)-3-butyn-2 -one }\end{array}$ & $\mathrm{C}_{15} \mathrm{H}_{24}$ & 204 & 701 & 21.70 & 3.41 \\
\hline 7-Acetyl-6-ethyl-1,1,4,4-tetramethyltetralin & $\mathrm{C}_{18} \mathrm{H}_{26} \mathrm{O}$ & 258 & 930 & 27.34 & 2.78 \\
\hline 2-Propanol,1,1-oxybis- & $\mathrm{C}_{18} \mathrm{H}_{32} \mathrm{O}_{2}$ & 134 & 892 & 7.10 & 2.67 \\
\hline $\begin{array}{c}\text { (-)- } \alpha \text {-Bisabolol oxide A: 2H-Pyran-3-ol, } \\
\left.\left.\text { tetrahydro-2,2,6-trimethyl-6-(4-methyl-3-cyclohexen-1-yl)-, [3S[3alpha,6alpha }\left(\mathrm{R}^{*}\right)\right]\right]\end{array}$ & $\mathrm{C}_{15} \mathrm{H}_{26} \mathrm{O}_{2}$ & 236 & 845 & 23.72 & 1.80 \\
\hline 7a-Isopropenyl-4,5-dimethyloctahydroinden-4-yl)methanol & $\mathrm{C}_{15} \mathrm{H}_{26} \mathrm{O}$ & 222 & 816 & 23.26 & 1.53 \\
\hline 2-phenylethanol & $\mathrm{C}_{8} \mathrm{H}_{10} \mathrm{O}$ & 122 & 921 & 9.29 & 1.39 \\
\hline D- Carvone: 2-Cyclohexen-1-one, 2-methyl-5-(1-methylethenyl)- & $\mathrm{C}_{10} \mathrm{H}_{14} \mathrm{O}$ & 150 & 938 & 12.76 & 1.36 \\
\hline Malonic acid: bis(1-methyl-2-hydroxyethyl)ether & $\mathrm{C}_{3} \mathrm{H}_{4} \mathrm{O}_{4}$ & 104 & 999 & 8.36 & 1.28 \\
\hline 1H-3a,7-Methanoazulene,2,3,6,7,8,8a-hexahydro-1,4,9,9-tetramethyl-(1à,3aà,7à,8aá)- & $\mathrm{C}_{15} \mathrm{H}_{24}$ & 204 & 868 & 18.28 & 0.97 \\
\hline Phthalic acid: 1,2-Benzenedicarboxylic acid, diethyl ester & $\mathrm{C}_{12} \mathrm{H}_{14} \mathrm{O}_{4}$ & 222 & 942 & 20.06 & 0.96 \\
\hline 1-Chloro-7-heptadecyne & $\mathrm{C}_{17} \mathrm{H}_{31} \mathrm{Cl}$ & 270 & 743 & 27.96 & 0.90 \\
\hline 1-chlorotetradecane & $\mathrm{C}_{14} \mathrm{H}_{29} \mathrm{Cl}$ & 232 & 733 & 8.83 & 0.87 \\
\hline Acetyl cedrene, Ethanone & $\mathrm{C}_{17} \mathrm{H}_{26} \mathrm{O}$ & 246 & 940 & 25.62 & 0.82 \\
\hline Nerol: (Z)-3,7-dimethyl-2,6-octadien-1-ol & $\mathrm{C}_{10} \mathrm{H}_{18} \mathrm{O}$ & 154 & 907 & 13.11 & 0.80 \\
\hline Methyl pimar-8-en-18-oate & $\mathrm{C}_{21} \mathrm{H}_{34} \mathrm{O}_{2}$ & 318 & 623 & 27.62 & 0.76 \\
\hline $\begin{array}{l}\text { Caryophyllene: Bicyclo[7.2.0]undec-4-ene, 4,11,11-trimethyl-8-methylene-, } \\
{\left[1 \mathrm{R}-\left(1 \mathrm{R}^{*}, 4 \mathrm{E}, 9 \mathrm{~S}^{*}\right)\right]_{-}^{-}}\end{array}$ & $\mathrm{C}_{15} \mathrm{H}_{24}$ & 204 & 888 & 17.39 & 0.68 \\
\hline $\begin{array}{c}\text { Alloaromadendrene: } \\
\text { (1aS,4aR,7S,7aS,7bR)-1,1,7-Trimethyl-4-methylendecahydro-1H-cyclopropa[e]azulen }\end{array}$ & $\mathrm{C}_{15} \mathrm{H}_{24}$ & 204 & 907 & 18.37 & 0.65 \\
\hline$\alpha$-Isomethyl ionone: 4-(2,6,6-Trimethyl 2-cyclohexen-1-yl)-3-methyl-3-buten-2-one & $\mathrm{C}_{14} \mathrm{H}_{22} \mathrm{O}$ & 206 & 890 & 18.92 & 0.64 \\
\hline 2-Pentadecanone, 6,10,14-trimethyl- & $\mathrm{C}_{18} \mathrm{H}_{36} \mathrm{O}$ & 268 & 876 & 27.21 & 0.43 \\
\hline
\end{tabular}




\subsection{Mortalities, Signs, Body Weight Changes, And Relative Kidney Weight}

There were no recorded mortalities among all experimental rats. The $\mathrm{CoCl}_{2-}$ exposed rats showed signs of dullness, fatigue, and lethargy. The degree of severity of the noticed signs was attenuated in both groups that were co-administered with MOEE (prophylactic and therapeutic). Exposure to $\mathrm{CoCl}_{2}$ was associated with a significant decrease in the body weight gain but no difference in the relative kidney weight in intoxicated rats in comparison with control rats. The inclusion of MOEE increased the body weight gain in the MOEE-supplemented group. Co-treatment of $\mathrm{CoCl}_{2}$-exposed rats with MOEE significantly improved the body weight gain in the prophylactic co-treated group compared with the $\mathrm{CoCl}_{2}$-intoxicated group.

\subsection{Renal Injury Markers and Protein Profile}

$\mathrm{CoCl}_{2}$ exposure was associated with a significant increase in the levels of urea and creatinine, compared to the control group. The co-administration of MOEE with $\mathrm{CoCl}_{2}$ significantly reduced the serum concentrations of both markers; the effects were more pronounced in the prophylactic $\left(\mathrm{MOEE} / \mathrm{CoCl}{ }_{2}+\mathrm{MOEE}\right)$ than the therapeutic group $\left(\mathrm{CoCl}_{2}+\mathrm{MOEE} / \mathrm{MOEE}\right)$. Although the serum levels of these biomarkers in both co-treated groups were modulated, they did not normalize to the control level. Moreover, $\mathrm{CoCl}_{2}$ exposure was associated with significantly lower levels of total proteins and albumin compared to the control group. This decrease was improved upon the administration of MOEE in a protective regimen, while it showed no change in the therapeutic co-treated group, compared with $\mathrm{CoCl}_{2}$-exposed group. On the other hand, the serum levels of globulins were decreased on $\mathrm{CoCl}_{2}$ exposure, compared with control group. The declined globulin level was significantly modulated to be normalized in the prophylactic (MOEE/CoCl $\left.\mathrm{Cl}_{2}+\mathrm{MOEE}\right)$ group, but non-significant changes were recorded in the therapeutic one compared with $\mathrm{CoCl}_{2}$-exposed group. The $\mathrm{A} / \mathrm{G}$ ratio showed non-significant differences among all groups (Table 2).

Table 2. Body weight change, relative kidney weight, kidney tissue injury markers, total protein variables in rats in response to MOEE administration $(400 \mathrm{mg} / \mathrm{kg}$ body weight (bw), orally) and/or $\mathrm{CoCl}_{2}$ treatment $(300 \mathrm{mg} / \mathrm{L}$ in drinking water).

\begin{tabular}{|c|c|c|c|c|c|}
\hline \multirow{2}{*}{ Parameters } & \multicolumn{4}{|c|}{ Experimental Groups } & \multirow[b]{2}{*}{$\mathrm{CoCl}_{2}+\mathrm{MOEE} / \mathrm{MOEE}$} \\
\hline & Control & MOEE & $\mathrm{CoCl}_{2}$ & $\mathrm{MOEE} / \mathrm{CoCl}_{2}+\mathrm{MOEE}$ & \\
\hline Body weight change (gm) & $12.00^{\mathrm{b}} \pm 1.09$ & $18.16^{\mathrm{a}} \pm 1.44$ & $\begin{array}{c}-11.00^{\mathrm{d}} \pm \\
0.73\end{array}$ & $-5.00^{c} \pm 2.67$ & $-8.00^{\mathrm{cd}} \pm 0.57$ \\
\hline Relative kidney weight & $0.25 \pm 0.01$ & $0.26 \pm 0.01$ & $0.27 \pm 0.02$ & $0.26 \pm 0.02$ & $0.28 \pm 0.02$ \\
\hline Kidney tissue injury markers & & & & & \\
\hline Urea $(\mathrm{mg} / \mathrm{dL})$ & $21.18^{\mathrm{d}} \pm 0.80$ & $20.54^{d} \pm 0.61$ & $43.48^{\mathrm{a}} \pm 1.69$ & $26.65^{c} \pm 1.15$ & $37.51^{\mathrm{b}} \pm 1.56$ \\
\hline $\begin{array}{l}\text { Creatinine }(\mathrm{mg} / \mathrm{dL}) \\
\text { Protein profile }\end{array}$ & $0.83^{d} \pm 0.02$ & $0.84^{\mathrm{d}} \pm 0.04$ & $1.97^{\mathrm{a}} \pm 0.06$ & $1.09^{c} \pm 0.05$ & $1.49^{b} \pm 0.06$ \\
\hline Total protein $(\mathrm{gm} / \mathrm{dL})$ & $6.47^{\mathrm{a}} \pm 0.25$ & $6.43^{a} \pm 0.29$ & $3.97^{\mathrm{c}} \pm 0.29$ & $5.39^{b} \pm 0.21$ & $4.20^{c} \pm 0.31$ \\
\hline Albumin $(\mathrm{gm} / \mathrm{dL})$ & $3.97^{\mathrm{a}} \pm 0.23$ & $4.09^{a} \pm 0.23$ & $2.34^{\mathrm{c}} \pm 0.16$ & $3.24^{b} \pm 0.08$ & $2.56^{b c} \pm 0.22$ \\
\hline Globulin (gm/dL) & $2.49^{\mathrm{a}} \pm 0.09$ & $2.35^{\mathrm{a}} \pm 0.13$ & $1.63^{b} \pm 0.15$ & $2.15^{\mathrm{ab}} \pm 0.18$ & $1.64^{b} \pm 0.12$ \\
\hline $\mathrm{A} / \mathrm{G}$ ratio & $1.60 \pm 0.09$ & $1.75 \pm 0.11$ & $1.46 \pm 0.07$ & $1.56 \pm 0.14$ & $1.56 \pm 0.12$ \\
\hline
\end{tabular}

Means within the same row bearing different superscripts $(a, b, c, d)$ are considered significantly varied $(p<0.05)$ (mean \pm SE). One-way ANOVA followed by Tukey's B post hoc test. MOEE: Moringa oleifera leave ethanolic extract, $\mathrm{CoCl}_{2}$ : Cobalt chloride-exposed group, $\mathrm{MOEE} / \mathrm{CoCl}_{2}+\mathrm{MOEE}$ : prophylaxis co-treated group, $\mathrm{CoCl}_{2}+\mathrm{MOEE} / \mathrm{MOEE}$ : therapeutic co-treated group.

\subsection{Oxidative Stress/Antioxidant Status Markers}

Significant elevations were found in renal tissue $\mathrm{H}_{2} \mathrm{O}_{2}$, malondialdehyde (MDA), and 8-OHdG concentrations in $\mathrm{CoCl}_{2}$-exposed rats, compared with control rats. The levels of $\mathrm{H}_{2} \mathrm{O}_{2}$ and 8-OhdG were significantly modulated by MOEE supplementation in both co-treated groups. This modulation was more prominent in the prophylactic group (MOEE/CoCl 2 MOEE); however, they still revealed a significant elevation compared with the control group. A significant modulation of the MDA level was recorded only in the prophylactic group, but not in therapeutic co-administered group in comparison with $\mathrm{CoCl}_{2}$-exposed rats. 
The previously mentioned increases were associated with significant decreases in the renal tissue antioxidant indices (SOD, CAT activities, and GSH content) in rats exposed to $\mathrm{CoCl}_{2}$ compared with the control group. In addition, the administration of MOEE was found to significantly improve the reduced levels when co-treated with $\mathrm{CoCl}_{2}$; this effect was more pronounced in the prophylactic co-treated group than the therapeutic co-treated one (Table 3).

Table 3. Antioxidants and oxidative stress variables in rats in response to MOEE administration (400 mg/kg bw, orally) and/or $\mathrm{CoCl}_{2}$ treatment (300 mg/L in drinking water).

\begin{tabular}{|c|c|c|c|c|c|}
\hline \multirow{2}{*}{ Parameters } & \multicolumn{4}{|c|}{ Experimental Groups } & \multirow[b]{2}{*}{$\mathrm{CoCl}_{2}+\mathrm{MOEE} / \mathrm{MOEE}$} \\
\hline & Control & MOEE & $\mathrm{CoCl}_{2}$ & $\mathrm{MOEE} / \mathrm{CoCl}_{2}+\mathrm{MOEE}$ & \\
\hline \multicolumn{6}{|l|}{ Antioxidants biomarkers } \\
\hline CAT activity (U/gm tissue) & $1.14^{\mathrm{a}} \pm 0.03$ & $1.21^{\mathrm{a}} \pm 0.05$ & $0.54^{\mathrm{d}} \pm 0.04$ & $0.97^{b} \pm 0.01$ & $0.73^{c} \pm 0.05$ \\
\hline GSH level (mmol/gm tissue) & $0.56^{\mathrm{a}} \pm 0.03$ & $0.55^{\mathrm{a}} \pm 0.03$ & $0.21^{\mathrm{d}} \pm 0.02$ & $0.42^{b} \pm 0.02$ & $0.32^{c} \pm 0.01$ \\
\hline \multicolumn{6}{|l|}{ Oxidative injury biomarkers } \\
\hline $8 \mathrm{OHdG}(\mathrm{ng} / \mathrm{mL})$ & $0.09^{\mathrm{d}} \pm 0.01$ & $0.07^{\mathrm{d}} \pm 0.01$ & $0.37^{\mathrm{a}} \pm 0.02$ & $0.16^{\mathrm{c}} \pm 0.01$ & $0.31^{b} \pm 0.01$ \\
\hline
\end{tabular}

Means within the same row bearing different superscripts $(a, b, c, d)$ are considered significantly varied $(p<0.05)$ (mean $\pm \mathrm{SE}$ ). One-way ANOVA followed by Tukey's B post hoc test. MOEE: Moringa oleifera leave ethanolic extract, $\mathrm{CoCl}_{2}$ : Cobalt chloride-exposed group, MOEE/ $\mathrm{CoCl}_{2}+\mathrm{MOEE}$ : prophylaxis co-treated group, $\mathrm{CoCl}_{2}+\mathrm{MOEE} / \mathrm{MOEE}$ : Therapeutic co-treated group, 8OHdG: 8-hydroxy-2-deoxyguanosine, CAT: catalase, GSH: glutathione, SOD: superoxide dismutase.

\subsection{Inflammatory Response Markers in Kidney Tissue}

The renal tissue concentrations of CRP, MPO, TNF- $\alpha$, and NO were significantly elevated in $\mathrm{CoCl}_{2}$-exposed rats compared with the control rats. The administration of MOEE alone was associated with non-significant decreases in their levels, except for CRP levels, which showed a significant decrease. The co-treatment of MOEE with $\mathrm{CoCl}_{2}$ significantly attenuated the elevation of these indices, particularly in the prophylactic co-treated rat's kidney more than therapeutic regimen, compared with $\mathrm{CoCl}_{2}$-exposed rats. Unfortunately, the recorded modulation in both co-administered groups did not attain the inflammatory response to the control value (Figure 4).
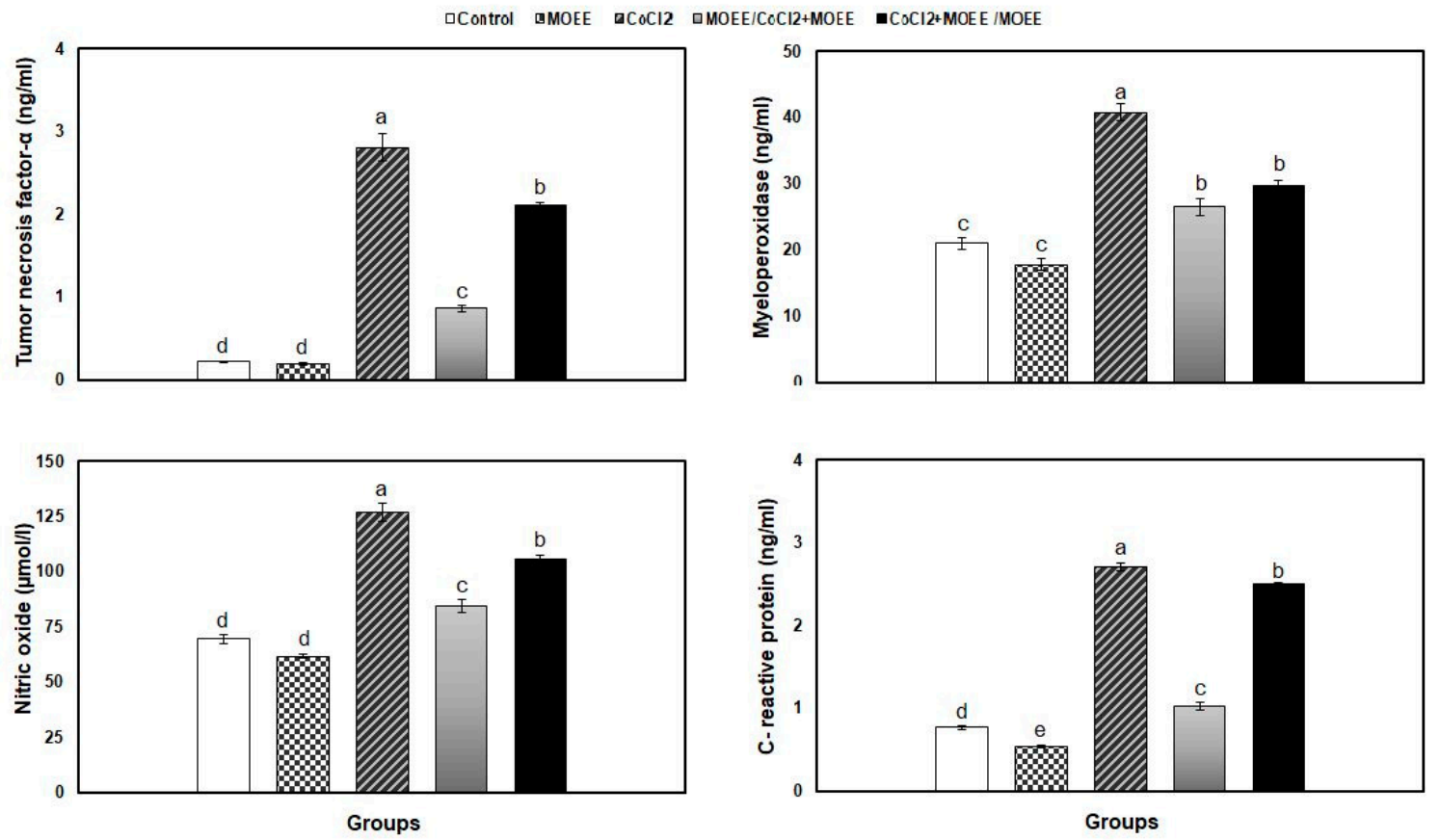

Figure 4. Inflammatory markers (nitric oxide, NO; tumor necrosis factor- $\alpha$, TNF- $\alpha$; myeloperoxidase, MPO; 
and C-reactive protein, $\mathrm{CRP}$ ) in the kidney tissue of rats in response to MOEE administration (400 mg/kg bw, orally) and/or $\mathrm{CoCl}_{2}$ treatment (300 mg/L in drinking water). Bars carrying different letters $(\mathrm{a}, \mathrm{b}, \mathrm{c}, \mathrm{d}, \mathrm{e})$ are significantly differently $(p<0.05)($ mean $\pm \mathrm{SE})$. One-way ANOVA followed by Tukey B post hoc test. MOEE: Moringa oleifera leave ethanolic extract-administered group, $\mathrm{CoCl}_{2}$ : Cobalt chloride-exposed group, $\mathrm{MOEE} / \mathrm{CoCl}_{2}+\mathrm{MOEE}$ : prophylaxis co-treated group, $\mathrm{CoCl}_{2}+\mathrm{MOEE} / \mathrm{MOEE}$ : therapeutic co-treated group.

\subsection{Relative mRNA Levels of Inflammatory Cytokines in the Kidney Tissue}

The relative expression of NF-kB and IL-6 in the kidney tissue was found to be significantly up-regulated in $\mathrm{CoCl}_{2}$-exposed rats, compared to the control group. MOEE administration significantly modulated the expression of NF-kB and IL-6 in both prophylaxis and therapeutic co-treated groups compared with the $\mathrm{CoCl}_{2}$-exposed group. In the prophylaxis co-treated group, such elevations were modulated to be non-significantly different from the control group, while in the therapeutic group, the down-regulated expression of the aforementioned genes was still significantly different and higher than the control group (Figure 5).

aControl aMOEE aCOCl2 aMOEE/COCl2+MOEE aCOCI2+MOEE/MOEE
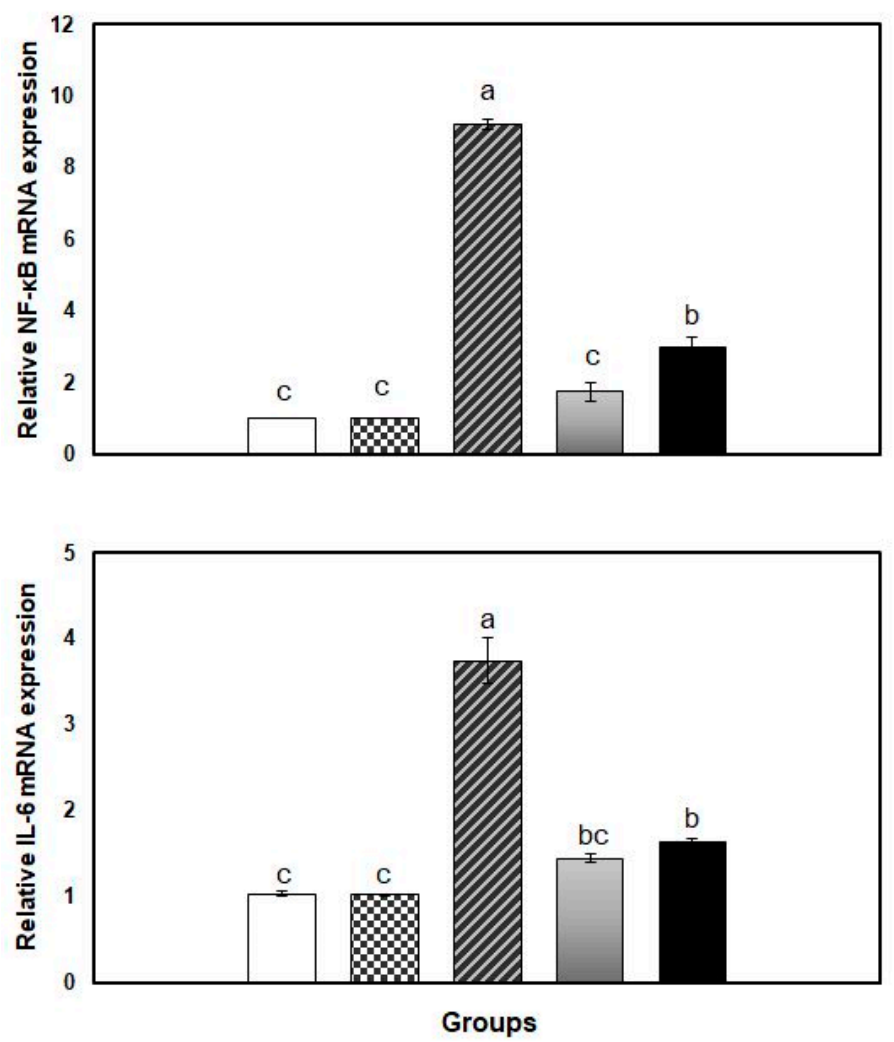

Figure 5. Relative expression of nuclear factor-kappa B (NF-kB) and interleukin (IL)-6 mRNA in the kidney tissue of rats in response to MOEE administration $\left(400 \mathrm{mg} / \mathrm{kg}\right.$ bw, orally) and/or $\mathrm{CoCl}_{2}$ treatment (300 mg/L in drinking water). The expression abundance of genes mRNA was normalized against the glyceraldehyde-3-phosphate dehydrogenase (GAPDH) internal control gene. Bars carrying different letters $(\mathrm{a}, \mathrm{b}, \mathrm{c})$ are significantly different $(p<0.05)$ (mean $\pm \mathrm{SE}$ ). One-way ANOVA followed by Tukey $\mathrm{B}$ post hoc test. MOEE: Moringa oleifera leave ethanolic extract-administered group, $\mathrm{CoCl}_{2}$ : Cobalt chloride-exposed group, $\mathrm{MOEE} / \mathrm{CoCl}_{2}+\mathrm{MOEE}$ : prophylaxis co-treated group, $\mathrm{CoCl}_{2}+\mathrm{MOEE} / \mathrm{MOEE}$ : therapeutic co-treated group. 


\section{Discussion}

The current study revealed the nephrotoxic effects of $\mathrm{CoCl}_{2}$ exposure, including inflammation and oxidative stress-mediated damage. On the other hand, MOEE supplementation was associated with significant decreases in the levels of renal injury, oxidative stress, and inflammatory response indices. This modulation was associated with down-regulation of the mRNA expression profile of genes that mediate the inflammatory response in the kidney tissue. Previously, various antioxidants of natural sources have shown an ameliorative efficacy against xenobiotics-induced toxicity in in vivo animal studies [11,37-40].

The reduced body weight gains upon $\mathrm{CoCl}_{2}$ exposure may be explained by the metabolic cost theory where the toxic stressors induce some metabolic changes that consume the organism's energy reserves to combat the effects of the toxicant or to activate repair mechanisms, resulting in an alteration of protein and carbohydrate metabolism [41]. On the other hand, the recorded increases in body weight gain in response to MOEE administration could be due to the desirable nutritional contents, including vitamins, amino acids, minerals, and fatty acids, besides various types of antioxidants including flavonoids, ascorbic acid, glucsinolates, carotenoids, and phenolics [25]. The phytochemical analysis of the MOEE used in the present study showed that the extract is rich in thymol that enhances the digestibility and antimicrobial efficiency against gut pathogens [42] and may be responsible for the advantageous influence of MO supplementation on animal performance. Moreover, the restoration of body weight noted in the prophylaxis co-treated group may be attributed to the growth-promoting potency of MO or the ability to hinder the oxidative injury induced by cobalt, reducing the stressful consequences of it in the exposed rats.

The nephrotoxic effects of $\mathrm{CoCl}_{2}$ were evidenced by the increase of serum creatinine and urea concentrations. The renal dysfunction includes the failure of the kidneys to scavenge the muscular metabolic waste product from the blood, resulting in the rise of creatinine levels in serum. In addition, when the rate of serum urea formation exceeds the rate of its clearance, the accumulation of serum urea occurs [35]. Further, alteration in the glomerular filtration, which refrains proteins and cells from being released into the urine, leads to hypoproteinemia (as recorded in the present study). Another explanation for protein content depletion is the interceding protein catabolism as an energy reserve to counter the existence stress and activate repair mechanisms [25].

Herein, MOEE co-administration with $\mathrm{CoCl}_{2}$ showed a nephroprotective efficiency through the improvement of the kidney function and protein synthesis. Such protection was also demonstrated against other xenobiotics, such as cadmium in rats, gentamicin in rabbits, and acetaminophen in mice [43-45]. Cobalt was found to accumulate in various body organs, including the liver, heart, and kidneys, in which the content of $\mathrm{Co}^{2+}$ correlated with the duration of exposure [46]. Therefore, the metal chelating potency against various metals such as lead, arsenic, and cobalt may explain MO protective properties against their toxic impact. This efficacy may be due to MO high calcium and ascorbic acid contents; calcium acts as an antagonist to metals/metalloids [11,47-49].

The deleterious influences of $\mathrm{CoCl}_{2}$ on the kidney tissue could be explained through the promotion of oxidative injury. Co (II) alters the cellular redox chemistry where it reacts in a Fenton-type reaction, mediating the excess production of ROS [50]. Indeed, ROS generation is a central mechanism of the genotoxicity caused by cobalt [51]. The current study showed that $\mathrm{CoCl}_{2}$ decreases the endogenous antioxidants' activities and increases $\mathrm{H}_{2} \mathrm{O}_{2}, \mathrm{MDA}$, and 8-OHdG formation in the renal tissue of intoxicated rats. Cobalt reacts with $\mathrm{H}_{2} \mathrm{O}_{2}$ in a phosphate buffer system, particularly in the existence of glutathione or histidine, to generate both superoxide and hydroxyl radicals, which damage DNA nucleotides [52]. Additionally, ROS can damage the cell membrane by reacting with the phospholipid moieties of the membrane polyunsaturated fatty acids, mediating lipid peroxidation. This was in accordance with the previous studies that demonstrated the $\mathrm{CoCl}_{2}$-induced oxidative injury in different body systems $[11,53]$.

The endogenous antioxidant capacity may be altered by excessive ROS generation, causing glutathione depletion and SOD inactivation (by $\mathrm{H}_{2} \mathrm{O}_{2}$ and superoxide radicals). Cobalt has a mimetic 
action and therefore displaces divalent cations such as $\mathrm{Zn}$ (II) or $\mathrm{Ca}$ (II) that are present in the active center of the antioxidant enzymes, leading to structural and functional impairments of enzymes and signal transduction pathways [54]. The genotoxic impacts of cobalt were previously described in human and rodent cells, including chromosome aberrations, single and double-strand breaks, sister chromatid exchanges, and micronuclei $[55,56]$. Cobalt ions can mediate an excessive generation of ROS that induce DNA double-strand breaks directly by breaking the DNA backbone [57]. Further, owing to the high affinity of cobalt ions to sulfhydryl groups, they may inhibit the enzymes that are involved in the polymerization and incision steps of the DNA repair machinery [56].

The ability of MOEE to alleviate oxidative stress could be due to its leaves' rich content of natural antioxidants, particularly flavonoids, including, quercetin, kaempferol, apigenin, and rutin [58]. Therefore, it possesses an anti-nephrotoxic potential as recorded in the case of acetaminophen-induced nephropathy [45]. Sreelatha and Padma [59] stated that MO leaf extract mitigated DNA damage in KB cells, increased their antioxidant enzymes, and ameliorated lipid peroxidation. Our GC-MS analysis showed that MOEE has several bioactive components such as thymol, bisabolol, eugenol, and cinnamaldehyde that exhibit strong antioxidant potency. The polyphenol eugenol was the main component in the tested extract. It possesses potent antioxidant activities owing to its phenolic group. Measuring the antioxidant activity of eugenol using 2,2'-azino-bis-3-ethylbenzothiazoline-6-sulfonic acid (ABTS) and 2,2-diphenyl-1-(2,4,6-trinitrophenyl) hydrazyl (DPPH) assays revealed that eugenol eliminates $76.9 \%$ and $90.8 \%$ of ABTS and DPPH free radicals, respectively [60]. The multiple free-radical scavenging testing method for five ROS (hydroxyl radical, superoxide, alkoxyl radical, peroxyl radical, and singlet oxygen) revealed a high singlet oxygen scavenging activity for eugenol [61]. Eugenol suppresses the production of superoxide anion by neutrophils via the inhibition of the Raf/MEK/ERK1/2/p47phox-phosphorylation pathway [62]. Moreover, it protects against ototoxicity and neurotoxicity induced by cisplatin and aluminium, respectively, via enhancing the activities of antioxidant enzymes and lowering the lipid peroxidation and 8-OHdG levels [63,64]. In vitro, the pretreatment of HCT116 cells with eugenol, $2 \mathrm{~h}$ prior to the mycotoxin citrinin exposure, significantly inhibited ROS generation, modulated the antioxidants enzymes activities, and reduced MDA production, protein-bound sulfhydryls level, and DNA fragmentation [65].

Another component, thymol, has well-described antioxidant, anti-inflammatory, anti-apoptotic, and organ-protective activities. It exhibited strong antioxidant properties against ketoprofen-induced pancreatic damage and inhibited DNA damage through the reduction of ROS and 8-OHdG levels [66]. $(-)-\alpha$-Bisabolol has been found to possess a high reducing activity that is directly proportional to its antioxidant potential [67]. It showed the ability to lessen oxidative stress and delay the development of various disease complications by countering ROS production as in isoproterenol-induced myocardial infarction [68]. Moreover, (-)- $\alpha$-bisabolol has exhibited in vivo and in vitro nephroprotective activity in kidney ischemic-reperfusion models in vivo, through the attenuation of functional alterations and reduction of lipid peroxidation and urinary kidney injury molecule-1 (uKIM-1) levels, which was associated with an improvement of GSH levels in male Wistar rats, and in vitro through enhancing cell viability and decreasing ROS production in Rhesus Monkey Kidney Epithelial Cells (LLC-MK2 cells) [69] and inhibiting NADPH oxidase enzyme activity in HK2 cells [70]. In addition, cinnamaldehyde inhibits ROS production in association with the up-regulation of the antioxidative enzyme heme-oxygenase 1 (HO-1). Further, it reduced the accumulation of MDA in vivo and accelerated the repair of UVB-mediated DNA damage in human keratinocytes in vitro [71]. Other authors showed that cinnamaldehyde ameliorated the high glucose-induced oxidative stress and apoptosis in cultured cardiomyocytes in a Transient receptor potential ankyrin subtype 1/ nuclear factor erythroid 2-related factor (TRPA1/Nrf2) pathway-dependent manner and mitigated cardiac oxidative stress and fibrosis in mice via an increased expression of antioxidant enzymes (HO-1, glutathione peroxidase-1 (GPx-1), quinone oxidoreductase-1 (NQO-1), and catalase) [72].

From the present findings, $\mathrm{CoCl}_{2}$ exposure leads to an increment of $\mathrm{H}_{2} \mathrm{O}_{2}$, reflecting the excess ROS formation, which facilitates the inflammatory response through improving the NF- $\mathrm{k} \beta$ - signaling 
pathway in rat's kidney. This was evidenced by the up-regulation of the mRNA expression pattern of the pro-inflammatory cytokine (IL-6) and NF- $\kappa \beta$ encoding genes, an improvement of NO production, and an elevation of MPO, TNF- $\alpha$, and CRP contents in the kidney. $\mathrm{CoCl}_{2}$ intoxication was associated with an oxidative damage-induced renal injury, which triggers secondary inflammatory events accompanied with cytokine release, tubular infiltration of leukocytes, and further exaggerating the renal injury [73]. Oxidative stress may actuate both cellular death and extracellular matrix breakdown (ECM). Consequently, necrotic cells and damaged ECM release different intracellular and extracellular molecules that stimulate inflammatory cascades via recognition by pattern recognition receptors (PRRs) [74]. Additionally, oxidative stress may actuate impairments within lipids and proteins, forming oxidation-specific epitopes that act as potential damage-associated molecular patterns ready to mediate innate immune cell responses to pro-inflammatory stimuli through binding to various PRRs.

NF- $\mathrm{KB}$ has a strategic position at the crossroad between oxidative stress and inflammation; it was proposed that ROS might represent key secondary mediators responsible for the activation of NF- $k B$ in response to multiple stimuli [75]. IL-6 is an important mediator of the inflammatory response as it participates in the development and differentiation of B- and T-cells, as well as the activation of acute phase proteins [76]; this was supported by the high level of CRP in the present study. Previous in vitro studies revealed that $\mathrm{CoCl}_{2}$ induces a pro-inflammatory response by increasing the expression of several pro-inflammatory chemokines as TNF- $\alpha$ and IL-6, which usually occur in response to NF-kB activation [77].

The elevated content of NO- induced cytotoxicity by reacting with other free radicals yielding the highly reactive peroxynitrite radical, which oxidizes cellular biomolecules such as DNA, lipids, and protein [78]. Additionally, the generation of large amounts of NO in the glomerulus can enhance the progression of renal failure in several forms of glomerulonephritis [79]. Moreover, the obtained results revealed that $\mathrm{CoCl}_{2}$ exposure significantly induced $\mathrm{MPO}$ activity (a marker for neutrophil infiltration), as when neutrophils are activated, they release MPO into the extracellular space during the inflammatory process. MPO catalyzes the synthesis of hypochlorous acid, which is a toxic agent to cellular components, intensifying the oxidative injury [80]. Histopathologically, Akinrinde et al. [81] observed an inflammatory cell infiltration in the renal tissue of rats exposed to cobalt.

The results of the present study showed that $\mathrm{MOEE}$ alleviated $\mathrm{CoCl}_{2}$-induced inflammation in co-treated rats and protected against the inflammatory-mediated exacerbation of renal damage in $\mathrm{CoCl}_{2}$ intoxicated rats. This suggests that MOEE combats the production of pro-inflammatory cytokines by suppressing the NF-kB pathway through the down-regulation of IL-6 and NF- $\mathrm{B}$ expression. Similarly, MOEE pretreatment of bovine mammary epithelial cells stimulated with lipopolysaccharide (LPS) blocked the activation of NF-кB [82]. Minaiyan et al. found that MO prevented inflammatory cells' infiltration and blocked the release of pro-inflammatory cytokines through the suppression of the NF- KB signaling pathway in experimental colitis [83].

Herein, the anti-inflammatory activities of MOEE are possibly attributed to its constituents of bisabolol, thymol, caryophyllene, and eugenol. Fontinele et al. [84] and Cavalcante et al. [85] demonstrated that treatment with (-)- $\alpha$-bisabolol reduced the inflammation in inflammatory pain and systemic infection experimental models in mice by the modulation of the release of pro- and anti-inflammatory cytokines and reducing $\mathrm{NO}$ production. It significantly prevented the increase of MPO activity, TNF- $\alpha$, and inducible nitric oxide synthase (iNOS) production in permanent focal cerebral ischemia [86]. Moreover, it attenuates inflammation by inhibiting nucleotide-binding oligomerization-like receptors P3 (NLRP3) inflammasome activation and Toll Like Receptor 4 (TLR4)-NFKB/ mitogen-activated protein kinases (MAPK) signaling pathways [87]. Eugenol is able to resist the release of pro-inflammatory mediators in lipopolysaccharide-induced injury [88,89]. $\beta$-Caryophyllene, a bicyclic sesquiterpene, has been reported to exert an anti-inflammatory activity, as it inhibited mRNA expression of iNOS, IL-1 $\beta$, IL-6, and Cyclooxygenase-2 (COX-2) in C6 microglial cells [90]. Moreover, previous studies have stated that thymol can elicit an anti-inflammatory action by suppressing pro-inflammatory signaling pathways and transcription factors such as 
p38 mitogen-activated protein kinases (MAPK), signal transducer and activator of transcription3 (STAT-3), NF-KB and activator protein-1 (AP-1), and TLR4-mediated Ras homolog family member A (RhoA)-dependent NF-kB in LPS-induced inflammation [91-93].

\section{Conclusions}

The current study showed that $\mathrm{CoCl}_{2}$ exposure induced oxidative stress, DNA damage, and inflammation in the kidney tissue of rats, indicating a nephrotoxic impact. However, MOEE administration (particularly in a prophylactic regimen) inhibited $\mathrm{CoCl}_{2}$-induced nephrotoxicity, probably via mitigating DNA damage, ROS mediated-oxidative injury, and inflammation (through modulating the expression pattern of targeted genes. Therefore, MOEE could be a good candidate for a supplement to alleviate oxidative injury and inflammatory responses, which occur in renal toxicities and pathological disorders. Nevertheless, further studies are needed to elucidate the molecular mechanisms underlying MOEE and its constituents' potency against the toxicities elicited by cobalt exposure.

Author Contributions: Conceptualization, S.R.K., and E.H.A.Z.; Data curation, M.M.A.-D., and A.A.; Formal analysis, R.A.E.-A.; Funding acquisition, M.M.A.-D. and H.A.E.-S.; Investigation, S.R.K., R.A.E.-A., and A.A.; Methodology, S.R.K., A.A., E.H.A.Z. and R.A.E.-A.; Project administration, M.M.A.-D. and H.A.E.-S.; Resources H.A.E.-S.; Software, M.M.A.-D.; Supervision S.R.K.; Writing- original draft S.R.K., and E.H.A.Z.; Writing-review \& editing, S.R.K., and A.A. All authors have read and agreed to the published version of the manuscript.

Funding: This work was funded by Researchers Supporting Project number (RSP-2019/19), King Saud University, Riyadh, Saudi Arabia.

Acknowledgments: The authors are grateful to king Saud University, Riyadh, Saudi Arabia, for funding this work through Researchers Supporting Project number (RSP-2019/19).

Conflicts of Interest: The authors declare no conflict of interest.

\section{References}

1. Jomova, K.; Valko, M. Advances in metal-induced oxidative stress and human disease. Toxicology 2011, 283, 65-87. [CrossRef]

2. Cheyns, K.; Nkulu, C.B.L.; Ngombe, L.K.; Asosa, J.N.; Haufroid, V.; De Putter, T.; Nawrot, T.; Kimpanga, C.M.; Numbi, O.L.; Kabylallunga, B.; et al. Pathways of human exposure to cobalt in Katanga, a mining area of the DR Congo. Sci. Total Environ. 2014, 490, 313-321. [CrossRef]

3. Mobasheri, A.; Proudman, C.J. Cobalt chloride doping in racehorses: Concerns over a potentially lethal practice. Veterinary J. 2015, 205, 335-338. [CrossRef]

4. Koizumi, H.; Takeuchi, Y.; Imai, H.; Kawai, T.; Yoneyama, T. Application of titanium and titanium alloys to fixed dental prostheses. J. Prosthodont. Res. 2019, 63, 266-270. [CrossRef]

5. Kitagawa, M.; Murakami, S.; Akashi, Y.; Oka, H.; Shintani, T.; Ogawa, I.; Inoue, T.; Kurihara, H. Current status of dental metalallergy in Japan. J. Prosthodont. Res. 2019, 63, 309-312. [CrossRef] [PubMed]

6. Pan, Y.; Lin, Y.; Jiang, L.; Lin, H.; Xu, C.; Lin, D.; Cheng, H. Removal of dental alloys and titanium attenuates trace metals and biological effects on liver and kidney. Chemosphere 2020, 243, 125205. [CrossRef] [PubMed]

7. International Agency for Research on Cancer (IARC). IARC Monographs on the Evaluation of Carcinogenic Risks to Humans; Cobalt in Hard Metals and Cobalt Sulfate, Gallium Arsenide, Indium Phosphide and Vanadium Pentoxide; World Health Organization: Lyon, France, 2006; Volume 86.

8. Leyssens, L.; Vinck, B.; Van Der Straeten, C.; Wuyts, F.; Maes, L. Cobalt toxicity in humans-A review of the potential sources and systemic health effects. Toxicology 2017, 387, 43-56. [CrossRef] [PubMed]

9. Uboldi, C.; Orsière, T.; Darolles, C.; Aloin, V.; Tassistro, V.; George, I.; Malard, V. Poorly soluble cobalt oxide particles trigger genotoxicity via multiple pathways. Part. Fibre Toxicol. 2015, 13, 5. [CrossRef]

10. Apostoli, P.; Catalani, S.; Zaghini, A.; Mariotti, A.; Poliani, P.L.; Vielmi, V.; Semeraro, F.; Duse, S.; Porzionato, A.; Macchi, V.; et al. High doses of cobalt induce optic and auditory neuropathy. Exp. Toxicol. Pathol. 2013, 65, 719-727. [CrossRef] 
11. Mohamed, A.A.R.; Metwally, M.M.; Khalil, S.R.; Salem, G.A.; Ali, H.A. Moringa oleifera extract attenuates the $\mathrm{CoCl}_{2}$ induced hypoxia of rat's brain: Expression pattern of HIF-1 $\alpha, \mathrm{NF}-\mathrm{kB}, \mathrm{MAO}$ and EPO. Biomed. Pharmacother. 2019, 109, 1688-1697. [CrossRef]

12. Zhu, H.; Liu, Y.; Hong, H.; Wang, W.; Liu, F. Protective effects of Zn2+ against cobalt nanoparticles and cobalt chloride-induced cytotoxicity of RAW 264.7 cells via ROS pathway. Biochem. Biophys. Res. Commun. 2017, 486, 357-363. [CrossRef] [PubMed]

13. Daliu, P.; Santini, A.; Novellino, E. A decade of nutraceutical patents: Where are we now in 2018? Expert Opin. Ther. Pat. 2018, 28, 875-882. [CrossRef] [PubMed]

14. Durazzo, A.; Lucarini, M.; Souto, E.B.; Cicala, C.; Caiazzo, E.; Izzo, A.A.; Novellino, E.; Santini, A. Polyphenols: A concise overview on the chemistry, occurrence, and human health. Phytother. Res. 2019, 33, 2221-2243. [CrossRef] [PubMed]

15. Khalil, S.R.; Salem, H.F.; Metwally, M.M.; Emad, R.M.; Elbohi, K.M.; Ali, S.A. Protective effect of Spirulina platensis against physiological, ultrastructural and cell proliferation damage induced by furan in kidney and liver of rat. Ecotoxicol. Environ. Saf. 2020, 192, 110256. [CrossRef] [PubMed]

16. Khalil, S.R.; Mohammed, A.T.; El-fattah, A.H.A.; Zaglool, A.W. Intermediate filament protein expression pattern and inflammatory response changes in kidneys of rats receiving doxorubicin chemotherapy and quercetin. Toxicol. Lett. 2018, 288, 89-98. [CrossRef]

17. Daghestani, M.H.; Selim, M.E.; Abd-Elhakim, Y.M.; Said, E.N.; El-Hameed, N.E.A.; Khalil, S.R.; El-Tawil, O.S. The role of apitoxin in alleviating propionic acid-induced neurobehavioral impairments in rat pups: The expression pattern of Reelin gene. Biomed. Pharmacother. 2017, 93, 48-56. [CrossRef]

18. Zakaria, N.; Khalil, S.R.; Awad, A.; Khairy, G.M. Quercetin Reverses Altered Energy Metabolism in the Heart of Rats Receiving Adriamycin Chemotherapy. Cardiovasc. Toxicol. 2018, 18, 109-119. [CrossRef]

19. Toughan, H.; Khalil, S.R.; El-Ghoneimy, A.A.; Awad, A.; Seddek, A.S. Effect of dietary supplementation with Spirulina platensis on Atrazine-induced oxidative stress-mediated hepatic damage and inflammation in the common carp (Cyprinus carpio L.). Ecotoxicol. Environ. Saf. 2018, 149, 135-142. [CrossRef]

20. Pandey, A.; Pandey, R.V.; Tripathi, P.; Gupta, P.P.; Haider, J.; Bhatt, S.; Singh, A.V. Moringa oleifera Lam. (Sahijan) -A plant with a plethora of diverse therapeutic benefits: An updated retrospection. Med. Aromat. Plants 2012, 1, 101. [CrossRef]

21. Stohs, S.J.; Hartman, M.J. Review of the safety and efficacy of Moringa oleifera. Phytother. Res. 2015, 29, 796-804. [CrossRef]

22. Sharifudin, S.A.; Fakurazi, S.; Hidayat, M.T.; Hairuszah, I.; Aris Mohd Moklas, M.; Arulselvan, P. Therapeutic potential of Moringa oleifera extracts against acetaminophen-induced hepatotoxicity in rats. Pharm. Biol. 2012, 51, 279-288. [CrossRef] [PubMed]

23. Taha, N.R.; Amin, H.A.; Sultan, A.A. The protective effect of Moringa oleifera leaves against cyclophosphamide-induced urinary bladder toxicity in rats. Tissue Cell 2015, 47, 94-104. [CrossRef] [PubMed]

24. Abdou, K.H.; Moselhy, W.A.; Mohamed, H.M.; El-Nahass, E.S.; Khalifa, A.G. Moringa oleifera leaves extract protects titanium dioxide nanoparticles-induced nephrotoxicity via $\mathrm{Nrf2} / \mathrm{HO}-1$ signaling and amelioration of oxidative stress. Biol. Trace Elem. Res. 2019, 187, 181-191. [CrossRef]

25. Khalil, S.R.; Abdel-Motal, S.M.; Abd-Elsalam, M.; El-Hameed, N.E.A.; Awad, A. Restoring strategy of ethanolic extract of Moringa oleifera leaves against Tilmicosin-induced cardiac injury in rats: Targeting cell apoptosis-mediated pathways. Gene 2020, 730, 144272. [CrossRef]

26. Khalil, S.R.; Mohammed, W.A.; Zaglool, A.W.; Elhady, W.M.; Farag, M.R. Inflammatory and oxidative injury is induced in cardiac and pulmonary tissue following fipronil exposure in Japanese quail: mRNA expression of the genes encoding interleukin 6, nuclear factor kappa B, and tumor necrosis factor-alpha. Environ. Poll. 2019, 251, 564-572. [CrossRef] [PubMed]

27. Lugrin, J.; Rosenblatt-Velin, N.; Parapanov, R.; Liaudet, L. The role of oxidative stress during inflammatory processes. Biol. Chem. 2014, 395, 203-230. [CrossRef]

28. Scheubert, K.; Hufsky, F.; Böcker, S. Computational mass spectrometry for small molecules. J. Cheminformatics 2013, 5, 12. [CrossRef]

29. Awoyemi, O.V.; Okotie, U.J.; Oyagbemi, A.A.; Omobowale, T.O.; Asenuga, E.R.; Ola-Davies, O.E.; Ogunpolu, B.S. Cobalt chloride exposure dose-dependently induced hepatotoxicity through enhancement 
of cyclooxygenase-2 (COX-2)/B-cell associated protein X (BAX) signaling and genotoxicity in Wistar rats. Environ. Toxicol. 2017, 32, 1899-1907. [CrossRef]

30. Ohkawa, H.; Ohishi, N.; Yagi, K. Assay for lipid peroxides in animal tissues by thiobarbituric acid reaction. Anal. Biochem. 1979, 95, 351-358. [CrossRef]

31. Sinha, A.K. Colorimetric assay of catalase. Anal. Biochem. 1972, 47, 389-394. [CrossRef]

32. Misra, H.P.; Fridovich, I. The role of superoxide anion in the autoxidation of epinephrine and a simple assay for superoxide dismutase. J. Biol. Chem. 1972, 247, 3170-3175. [PubMed]

33. Beutler, E. Improved method for the determination of blood glutathione. J. Lab. Clin. Med. 1963, 61, 882-888. [PubMed]

34. Khalil, S.R.; Awad, A.; Mohammed, H.H.; Nassan, M.A. Imidacloprid insecticide exposure induces stress and disrupts glucose homeostasis in male rats. Environ. Toxicol. Pharmacol. 2017, 55, 165-174. [CrossRef]

35. Awad, A.; Khalil, S.R.; Farag, M.R.; Nassan, M.A. Differential susceptibility of kidneys and livers to proliferative processes and transcriptional level of the genes encoding desmin, vimentin, connexin 43 , and nestin in rats exposed to furan. Ecotoxicol. Environ. Saf. 2018, 162, 235-244. [CrossRef] [PubMed]

36. Livak, K.J.; Schmittgen, T.D. Analysis of relative gene expression data using real-time quantitative PCR and the 2-DDCT method. Methods 2001, 25, 402-408. [CrossRef] [PubMed]

37. Moustafa, G.G.; Khalil, S.; Hussein, M.M.; Labib, M. The cytotoxic and ultrastrctural perturbations of aluminum exposed Nile catfish with special reference to the mitigating effect of vitamin C. Life Sci. J. 2012, 9, 5198-5210.

38. Khalil, S.R.; Hussein, M.M. Neurotransmitters and neuronal apoptotic cell death of chronically aluminum intoxicated Nile catfish (Clarias gariepinus) in response to ascorbic acid supplementation. Neurotoxicology 2015, 51, 184-191. [CrossRef]

39. Khalil, S.R.; Khalifa, H.A.; Abdel-Motal, S.M.; Mohammed, H.H.; Elewa, Y.H.; Mahmoud, H.A. Spirulina platensis attenuates the associated neurobehavioral and inflammatory response impairments in rats exposed to lead acetate. Ecotoxicol. Environ. Saf. 2018, 157, 255-265. [CrossRef]

40. Khalil, S.R.; Elhady, W.M.; Elewa, Y.H.; El-Hameed, N.E.A.; Ali, S.A. Possible role of Arthrospira platensis in reversing oxidative stress-mediated liver damage in rats exposed to lead. Biomed. Pharmacother. 2018, 97, 1259-1268. [CrossRef]

41. Khalil, S.R.; Awad, A.; Mohammed, H.H. Behavioral response and gene expression changes in fipronil-administered male Japanese quail (Coturnix japonica). Environ. Poll. 2017, 223, 51-61. [CrossRef]

42. Hashemipour, H.; Kermanshahi, H.; Golian, A.; Veldkamp, T. Effect of thymol and carvacrol feed supplementation on performance, antioxidant enzyme activities, fatty acid composition, digestive enzyme activities, and immune response in broiler chickens. Poult. Sci. 2013, 92, 2059-2069. [CrossRef] [PubMed]

43. Vinodini, N.A.; Chatterjee, P.K.; Chatterjee, P.; Chakraborti, S.; Nayanatara, A.K.; Bhat, R.M.; Rashmi, K.S.; Suman, V.B.; Shetty, S.B.; Pai, S.R. Protective role of aqueous leaf extract of Moringa oleifera on blood parameters in cadmium exposed adult Wistar albino rats. Int. J. Curr. Res. Acad. Rev. 2015, 3, 192-199.

44. Ouédraogo, M.; Lamien-Sanou, A.; Ramdé, N.; Ouédraogo, A.S.; Ouédraogo, M.; Zongo, S.P.; Goumbri, O.; Duez, P.; Guissou, P.I. Protective effect of Moringa oleifera leaves against gentamicin-induced nephrotoxicity in rabbits. Exp. Toxicol. Pathol. 2013, 65, 335-339. [CrossRef] [PubMed]

45. Karthivashan, G.; Kura, A.U.; Arulselvan, P.; Isa, N.M.; Fakurazi, S. The modulatory effect of Moringa oleifera leaf extract on endogenous antioxidant systems and inflammatory markers in an acetaminophen-induced nephrotoxic mice model. PeerJ 2016, 4, e2127. [CrossRef]

46. Simonsen, L.O.; Harbak, H.; Bennekou, P. Cobalt metabolism and toxicology-A brief update. Sci. Total Environ. 2012, 432, 210-215. [CrossRef]

47. Velaga, M.K.; Daughtry, L.K.; Jones, A.C.; Yallapragada, P.R.; Rajanna, S.; Rajanna, B. Attenuation of lead-induced oxidative stress in rat brain, liver, kidney and blood of male Wistar rats by Moringa oleifera seed powder. J. Environ. Pathol. Toxicol. Oncol. 2014, 33, 323-337. [CrossRef]

48. Gupta, R.; Kannan, G.M.; Sharma, M.; Flora, S.J. Therapeutic effects of Moringa oleifera on arsenic-induced toxicity in rats. Environ. Toxicol. Pharmacol. 2005, 20, 456-464. [CrossRef]

49. Flora, S.J.S. Nutritional components modify metal absorption, toxicresponse and chelation therapy. J. Nutr. Environ. Med. 2002, 12, 53-67. [CrossRef] 
50. Wang, X.Y.; Yokoi, I.; Liu, J.K.; Mori, A. Cobalt (II) and nickel (II) ions as promoters of free radicals in vivo: Detected directly using electron spin resonance spectrometry in circulating blood in rats. Arch. Biochem. Biophys. 1993, 306, 402-406. [CrossRef]

51. Zeeshan, M.; Murugadas, A.; Ghaskadbi, S.; Ramaswamy, B.R.; Akbarsha, M.A. Ecotoxicological assessment of cobalt using Hydra model: ROS, oxidative stress, DNA damage, cell cycle arrest, and apoptosis as mechanisms of toxicity. Environ. Poll. 2017, 224, 54-69. [CrossRef]

52. Yamamoto, K.; Inoue, S.; Yamazaki, A.; Yoshinaga, T.; Kawanishi, S. Site-specific DNA damage induced by cobalt(II) ion and hydrogen peroxide: Role of singlet oxygen. Chem. Res. Toxicol. 1989, 2, 234-239. [CrossRef] [PubMed]

53. Oyagbemi, A.A.; Omobowale, T.O.; Awoyomi, O.V.; Ajibade, T.O.; Falayi, O.O.; Ogunpolu, B.S.; Okotie, U.J.; Asenuga, E.R.; Adejumobi, O.A.; Hassan, F.O.; et al. Cobalt chloride toxicity elicited hypertension and cardiac complication via induction of oxidative stress and upregulation of COX-2/Bax signaling pathway. Hum. Exp. Toxicol. 2019, 38, 519-532. [CrossRef] [PubMed]

54. Valko, M.; Morris, H.; Cronin, M.T. Metals, toxicity and oxidative stress. Curr. Med. Chem. 2005, 12, 1161-1208. [CrossRef]

55. Lison, D.; DeBoeck, M.; Verougstraete, V.; Kirsch-Volder, M. Update on the genotoxicity and carcinogenicity of cobalt compounds. Occup. Environ. Med. 2001, 58, 619-625. [CrossRef] [PubMed]

56. Beyersmann, D.; Hartwig, A. Carcinogenic metal compounds: Recent insights into molecular and cellular mechanisms. Arch. Toxicol. 2008, 82, 493-512. [CrossRef] [PubMed]

57. Alarifi, S.; Ali, D.; Al Omar Suliman, Y.; Ahamed, M.; Siddiqui, M.A.; Al-Khedhairy, A.A. Oxidative stress contributes to cobalt oxide nanoparticles-induced cytotoxicity and DNA damage in human hepatocarcinoma cells. Int. J. Nanomed. 2013, 8, 189.

58. Tumer, T.B.; Rojas-Silva, P.; Poulev, A.; Raskin, I.; Waterman, C. Direct and indirect antioxidant activity of polyphenol-and isothiocyanate-enriched fractions from Moringa oleifera. J. Agr. Food Chem. 2015, 63, 1505-1513. [CrossRef]

59. Sreelatha, S.; Padma, P.R. Modulatory effects of Moringa oleifera extracts against hydrogen peroxide-induced cytotoxicity and oxidative damage. Hum. Exp. Toxicol. 2011, 30, 1359-1368. [CrossRef]

60. Kim, D.Y.; Won, K.J.; Hwang, D.I.; Park, S.M.; Kim, B.; Lee, H.M. Chemical Composition, Antioxidant and Anti-melanogenic Activities of Essential Oils from Chrysanthemum boreale Makino at Different Harvesting Stages. Chem. Biodivers. 2018, 15, e1700506. [CrossRef]

61. Sueishi, Y.; Nii, R. Comparative Profiling of Clove Extract and Its Component Antioxidant Activities Against Five Reactive Oxygen Species Using Multiple Free Radical Scavenging. Food Sci. Technol. Res. 2019, 25, 885-890. [CrossRef]

62. Chniguir, A.; Pintard, C.; Liu, D.; Dang, P.M.C.; El-Benna, J.; Bachoual, R. Eugenol prevents fMLF-induced superoxide anion production in human neutrophils by inhibiting ERK1/2 signaling pathway and p47phox phosphorylation. Sci. Rep. 2019, 9, 1-11. [CrossRef]

63. Sakat, M.S.; Kilic, K.; Akdemir, F.N.E.; Yildirim, S.; Eser, G.; Kiziltunc, A. The effectiveness of eugenol against cisplatin-induced ototoxicity. Braz. J. Otorhinolaryngol. 2019, 85, 766-773. [CrossRef]

64. Mesole, S.B.; Alfred, O.O.; Yusuf, U.A.; Lukubi, L.; Ndhlovu, D. Apoptotic Inducement of Neuronal Cells by Aluminium Chloride and the Neuroprotective Effect of Eugenol in Wistar Rats. Oxid. Med. Cell. Longev. 2020, 2020, 8425643. [CrossRef] [PubMed]

65. Salah, A.; Bouaziz, C.; Amara, I.; Abid-Essefi, S.; Bacha, H. Eugenol protects against citrinin-induced cytotoxicity and oxidative damages in cultured human colorectal HCT116 cells. Environ. Sci. Poll. Res. 2019, 26, 31374-31383. [CrossRef] [PubMed]

66. Deniz, G.Y. The Protective Effects of Thymol Against Ketoprofen Induced Damages on Pancreatic Acinar and Islet of Langerhans Cells in Rats. J. Essent. Oil Bear. Plants 2019, 22, 604-613. [CrossRef]

67. Meeran, M.F.N.; Laham, F.; Al-Taee, H.; Azimullah, S.; Ojha, S. Protective effects of $\alpha$-bisabolol on altered hemodynamics, lipid peroxidation, and nonenzymatic antioxidants in isoproterenol-induced myocardial infarction: In vivo and in vitro evidences. J. Biochem. Mol. Toxicol. 2018, 32, e22200. [CrossRef]

68. Meeran, M.F.N.; Laham, F.; Azimullah, S.; Tariq, S.; Ojha, S. $\alpha$-Bisabolol abrogates isoproterenol-induced myocardial infarction by inhibiting mitochondrial dysfunction and intrinsic pathway of apoptosis in rats. Mol. Cell. Biochem. 2019, 453, 89-102. [CrossRef] 
69. Sampaio, T.L.; de Menezes, R.R.P.P.B.; da Costa, M.F.B.; Meneses, G.C.; Arrieta, M.C.V.; Chaves Filho, A.J.M.; de Morais, G.B.; Liborio, A.B.; Alves, R.S.; Evangelista, J.S.A.M.; et al. Nephroprotective effects of (-)- $\alpha$-bisabolol against ischemic-reperfusion acute kidney injury. Phytomedicine 2016, 23, 1843-1852. [CrossRef] 
70. Sampaio, T.L.; Menezes, R.R.P.P.B.; Lima, D.B.; Silva, R.A.C.; de Azevedo, I.E.P.; Magalhães, E.P.; Marinho, M.M.; Santos, R.P.; Martins, A.M.C. Involvement of NADPH-oxidase enzyme in the nephroprotective effect of $(-)$ - $\alpha$-bisabolol on HK2 cells exposed to ischemia-Reoxygenation. Eur. J. Pharmacol. 2019, 855, 1-9. [CrossRef]

71. Tanaka, Y.; Uchi, H.; Furue, M. Antioxidant cinnamaldehyde attenuates UVB-induced photoaging. J. Dermatol. Sci. 2019, 96, 151-158. [CrossRef]

72. Wang, D.; Hou, J.; Yang, Y.; Zhou, P.; Liu, S.; Wan, J.; Wang, P. Cinnamaldehyde Ameliorates High-Glucose-Induced Oxidative Stress and Cardiomyocyte Injury Through Transient Receptor Potential Ankyrin 1. J. Cardiovasc. Pharmacol. 2019, 74, 30-37. [CrossRef] [PubMed]

73. Sanz, A.B.; Santamaria, B.; Ruiz-Ortega, M.; Egido, J.; Ortiz, A. Mechanisms of renal apoptosis in health and disease. J. Am. Soc. Nephrol. 2008, 19, 1634-1642. [CrossRef] [PubMed]

74. Chan, J.K.; Roth, J.; Oppenheim, J.J.; Tracey, K.J.; Vogl, T.; Feldmann, M.; Horwood, N.; Nanchahal, J. Alarmins: Awaiting a clinical response. J. Clin. Investig. 2012, 122, 2711-2719. [CrossRef] [PubMed]

75. Gloire, G.; Legrand-Poels, S.; Piette, J. NF- $\mathrm{kB}$ activation by reactive oxygen species: Fifteen years later. Biochem. Pharmacol. 2006, 72, 1493-1505. [CrossRef]

76. Madrigal-Estebas, L.; Doherty, D.G.; O'Donoghue, D.P.; Feighery, C.; O'Farrelly, C. Differential expression and upregulation of interleukin-1a, interleukin- $1 \mathrm{~b}$ and interleukin- 6 by freshly isolated human small intestinal epithelial cells. Mediat. Inflamm. 2002, 11, 313-319. [CrossRef]

77. Pedersen, B.K. Muscles and their myokines. J. Exp. Biol. 2011, 214, 337-346. [CrossRef]

78. Radi, R. Peroxynitrite, a stealthy biological oxidant. J. Biol. Chem. 2013, 288, 26464-26472. [CrossRef]

79. Cook, H.T.; Ebrahim, H.; Jansen, A.S.; Foster, G.R.; Largen, P.; Cattell, V. Expression of the gene for inducible nitric oxide synthase in experimental glomerulonephritis in the rat. Clin. Exp. Immunol. 1994, 97, 315-320. [CrossRef]

80. Arnhold, J.; Osipov, A.N.; Spalteholz, H.; Panasenko, O.M.; Schiller, J. Effects of hypochlorous acid on unsaturated phosphatidylcholines. Free Radic. Biol. Med. 2001, 31, 1111-1119. [CrossRef]

81. Akinrinde, A.S.; Oyagbemi, A.A.; Omobowale, T.O.; Asenuga, E.R.; Ajibade, T.O. Alterations in blood pressure, antioxidant status and caspase 8 expression in cobalt chloride-induced cardio-renal dysfunction are reversed by Ocimum gratissimum and gallic acid in Wistar rats. J. Trace Elem. Med. Biol. 2016, 36, $27-37$. [CrossRef]

82. Cheng, W.N.; Jeong, C.H.; Seo, H.G.; Han, S.G. Moringa Extract Attenuates Inflammatory Responses and Increases Gene Expression of Casein in Bovine Mammary Epithelial Cells. Animals 2019, 9, 391. [CrossRef] [PubMed]

83. Minaiyan, M.; Asghari, G.; Taheri, D.; Saeidi, M.; Nasr-Esfahani, S. Anti-inflammatory effect of Moringa oleifera Lam. seeds on acetic acid-induced acute colitis in rats. Avicenna J. Phytomed. 2014, 4, 127-136. [PubMed]

84. Fontinele, L.L.; Heimfarth, L.; Pereira, E.W.M.; Rezende, M.M.; Lima, N.T.; de Carvalho, Y.M.B.G.; Pires, E.A.M.; Guimarães, A.G.; de Carvalho, M.T.B.; Barreto, R.S.S.; et al. Anti-hyperalgesic effect of (-)- $\alpha$-bisabolol and (-)- $\alpha$-bisabolol/ $\beta$-Cyclodextrin complex in a chronic inflammatory pain model is associated with reduced reactive gliosis and cytokine modulation. Neurochem. Int. 2019, 131, 104530. [CrossRef] [PubMed]

85. Cavalcante, H.A.O.; Silva-Filho, S.E.; Wiirzler, L.A.M.; Cardia, G.F.E.; Uchida, N.S.; Silva-Comar, F.M.S.; Bersani-Amado, C.A.; Cuman, R.K.N. Effect of (-)- $\alpha$-Bisabolol on the Inflammatory Response in Systemic Infection Experimental Model in C57BL/6 Mice. Inflammation 2020, 43(1), 193-203. [CrossRef]

86. Fernandes, M.Y.D.; do Carmo, M.R.S.; Fonteles, A.A.; de Sousa Neves, J.C.; da Silva, A.T.A.; Pereira, J.F.; Ferreira, E.O.; Lima, N.M.R.; Neves, K.R.T.; de Andrade, G.M. (-)- $\alpha$-bisabolol prevents neuronal damage and memory deficits through reduction of proinflammatory markers induced by permanent focal cerebral ischemia in mice. Eur. J. Pharmacol. 2019, 842, 270-280. [CrossRef]

87. Meeran, M.N.; Azimullah, S.; Laham, F.; Tariq, S.; Goyal, S.N.; Adeghate, E.; Ojha, S. $\alpha$-Bisabolol protects against $\beta$-adrenergic agonist-induced myocardial infarction in rats by attenuating inflammation, lysosomal dysfunction, NLRP3 inflammasome activation and modulating autophagic flux. Food Funct. 2020, 11, 965-976. [CrossRef] 
88. Lee, Y.Y.; Hung, S.L.; Pai, S.F.; Lee, Y.H.; Yang, S.F. Eugenol suppressed the expression of lipopolysaccharide-induced proinflammatory mediators in human macrophages. J. Endod. 2007, 33, 698-702. [CrossRef]

89. Magalhães, C.B.; Riva, D.R.; DePaula, L.J.; Brando-Lima, A.; Koatz, V.L.; Leal-Cardoso, J.H.; Zin, W.A.; Faffe, D.S. In vivo anti-inflammatory action of eugenol on lipopolysaccharide-induced lung injury. J. Appl. Physiol. 2010, 108, 845-851. [CrossRef]

90. Chang, H.J.; Kim, J.M.; Lee, J.C.; Kim, W.K.; Chun, H.S. Protective effect of $\beta$ caryophyllene, a natural bicyclic sesquiterpene, against cerebral ischemic injury. J. Med. Food 2013, 16, 471-480. [CrossRef]

91. Wan, L.; Meng, D.; Wang, H.; Wan, S.; Jiang, S.; Huang, S.; Wei, L.; Yu, P. Preventive and therapeutic effects of thymol in a lipopolysaccharide-induced acute lung injury mice model. Inflammation 2018, 41, 183-192. [CrossRef]

92. Wu, H.; Jiang, K.; Yin, N.; Ma, X.; Zhao, G.; Qiu, C.; Deng, G. Thymol mitigates lipopolysaccharide-induced endometritis by regulating the TLR4- and ROS-mediated NF-kappaB signaling pathways. Oncotarget 2017, 8, 20042-20055. [PubMed]

93. Wang, Q.; Cheng, F.; Xu, Y.; Zhang, J.; Qi, J.; Liu, X.; Wang, R. Thymol alleviates lipopolysaccharide-stimulated inflammatory response via downregulation of RhoA-mediated NF- $\mathrm{kB}$ signalling pathway in human peritoneal mesothelial cells. Eur. J. Pharmacol. 2018, 833, 210-220. [CrossRef] [PubMed]

(C) 2020 by the authors. Licensee MDPI, Basel, Switzerland. This article is an open access article distributed under the terms and conditions of the Creative Commons Attribution (CC BY) license (http://creativecommons.org/licenses/by/4.0/). 